\title{
Determinants of Success of University Students in Vietnam: An Empirical Study
}

\author{
Lan T. N. NGUYEN ${ }^{1}$, Thao T. THAN², Tan G. NGUYEN ${ }^{3}$
}

Received: August 01, 2020 Revised: September 06, 2020 Accepted: September 10, 2020

\begin{abstract}
This paper investigates the determinants of students' success in Vietnam through conducting online interviews and surveys with 2,500 Vietnamese students at eight famous universities in Vietnam. By applying both SPSS 22 and STATA software, the study is to evaluate the impact of four driver factors, which affect GPA, language efficacy, and personal achievement. These factors are psychological perspective, home environmental, student demographic, and school environmental. The research results emphasize a positive effect of psychological and home-environmental determinants, but the negative effect of school environmental factors on the students' success. Besides, the relationship between demographics and student success was tested and indicated that male students have a better language learning ability, but a low level of academic achievement than female students. The results also point out the impact of religious affiliation and ethnicity on personal achievement. Non-religious students are better achievers than those having a religion or those in minority ethnicity. Moreover, accumulated schooling years are negatively associated with students' success. The more working experience students accrued, the higher possibility they are successful. Finally, the finding provides an insight into students' success that might be useful to government authorities and other universities in designing policies for enhancing the quality of education.
\end{abstract}

Keywords: Student Satisfaction, Academic Achievement, Education Quality, Higher Education

JEL Classification Code: M10, M12, I20, I21

\section{Introduction}

Nowadays, the students' success plays an important role in producing the best-qualified graduates who will become great leaders and human capital for their country, thus being responsible for the national economic and social development. The students' success in universities should be a concern, not only to the administrators and educators, but also to corporations in the labor market. Recently, while the number of students attending universities has been

${ }^{1}$ First Author and Corresponding Author. School of Accounting and Auditing, Van Lang University, Ho Chi Minh City, Vietnam [Postal Address: 45 Nguyen Khac Nhu Street, Co Giang Ward, District 1, Ho Chi Minh City, 700000, Vietnam] Email: ntnlan@vanlanguni.edu.vn ${ }^{2}$ School of Advanced Education Programs, National Economics University, Vietnam. Email: thanthachthao@gmail.com

${ }^{3}$ School of Finance and Banking, Banking Academy, Vietnam. Email: ntan980@gmail.com

(c) Copyright: The Author(s)

This is an Open Access article distributed under the terms of the Creative Commons Attribution Non-Commercial License (https://creativecommons.org/licenses/by-nc/4.0/) which permits unrestricted non-commercial use, distribution, and reproduction in any medium, provided the original work is properly cited. increasing sharply, the educational outcomes determined by the human capital quality in developing countries has declined gradually (United Nations, 2019). As a result, the number of unemployed graduate students has been raising by approximately 287.000 per year, accounted for $3,09 \%$ of the number of unemployed people (Ministry of Labour, Invalids and Social Affairs, 2019).

Based on statistics from Vietnam Works (2019), the workforce shortage in enterprises is nearly $80 \%$, and the reason behind that is the lack of professional skills, specialized knowledge, and practical experience to be employed. Thus, it is clear that the number of graduate students in Vietnam has increased, but their quality has not corresponded with the business requirements. Also, the demands for required skills are becoming expansive because these skills, such as technical skills, communication skills, customer handling, and team working, are irreplaceable in any organization (Green, 2003; Hillage, 2002; Nguyen et al., 2019). Hence, identifying the key factors influencing students' success is very necessary to design an effective learning environment to improve education quality before enhancing labor productivity and attaining sustainable development in Vietnam. 
Over time, students' success refers to different aspects, which are defined occasionally based on its correlation with socio-economic (Rahman et al., 2020; Hearn, 2006), psychology (Bean \& Eaton, 2002), business (Rochelle \& Dotterweich, 2007), and education (Ewell \& Wellman, 2007; Kim, 2019). Nevertheless, the most popular definition of students' success is given by Kuh et al. (2006) who argue that students' success represents their academic achievement, engagement in educationally purposeful activities, learning satisfaction, acquisition of desired knowledge, skills and competencies, persistence, attainment of educational objectives, and post-college performance. However, York et al. (2015) point out that the term students' success can be used interchangeably with academic success as inclusive of academic achievement, satisfaction, acquisition of skills and competencies, persistence, attainment of learning outcomes, and career success. By analyzing keywords searched in ERIC, EBSCO, and JSTOR databases, we expend their research to include the terms like "academic achievement," "academic success," "student learning," "academic performance," and those research lead to several outcomes related to academic success such as GPA, critical thinking, and self-efficiency (Aljaaidis et al., 2020). Thus, our research will focus on an individual's academic performance as an outcome variable of academic success.

Theoretically, numerous researchers and practitioners have attempted to determine and measure students' success following many different theories, such as coursespecific evaluations (Halamandaris \& Power, 1999), firstyear examination scores (Busato et al., 2000), final-year examination scores (Fruyt \& Mervielde, 1996), and grade point average (GPA) (Goff \& Ackerman, 1992), with the focus on student academic success in the tertiary (Phuc et al., 2020). Furthermore, researchers in the field of educational psychology have also investigated academic success, which is assessed by GPA (Savia Coutinho, 2007), the number of accumulated credits (Zajacova et al., 2005), and persistence rate (Vuong et al., 2010). Besides, by evaluating students' success based on GPA and graduation rate in diverse faculties in Göttingen University, Danilowicz-Gösele et al. (2017) explain that the conceptual framework of university success consists of three variables: the probability of finishing studies with a degree, the probability of finishing a chosen field of studies with a degree, and the accumulated grade of the final university degree. Although there are various approaches in measuring students' success, all previous authors have utilized the grades or scores to assess student success, which is indispensable. Therefore, in this study, we narrow down the definition of students' success by using an outcome variable, called GPA, measuring success in each program the student enrolled in.

Asian people often struggle to learn English, particularly Chinese (Yeung, 2017), Japanese (Shoji, 2018), and
Vietnamese (Dao, 2018), while the role of English language proficiency is undeniable in the immigrating world (Ward, 2020), especially for getting international jobs (Pinon \& Haydon, 2010). Also, English is the most spoken language in the world, which is used by over 1.5 billion people (Sawe, 2019). Thus, it is not only the most widely used tool in academic works, but also facilitates enhancing personal education and learning in prestigious universities in the UK, United States, and Australia (Englishaccess, 2019). Although Addow et al. (2013) and Wilson and Komba (2012) point out a weak relationship between English language proficiency and academic performance, Martirosyan et al. (2015) and Graham (1987) argue that the lack of language proficiency will result in weaknesses in academic performance. They confirm the importance of language proficiency in shaping students' academic performance, so it prompted our research to add English proficiency language to measure academic success.

Vietnamese experts, however, tend to narrow down the definition of students' success, referring it to a specific aspect as learning motivation, self-study, and learning outcomes. Besides, these researchers also find that many factors influenced academic performance, such as age, gender, faculty, self-consciousness learning, attention of a parent, career and family orientation, family encouragement, friend encouragement, a trained teacher, and adequate facilities (Nguyen, 2018; Truong, 2014; Nguyen, 2016; Nguyen et al., 2017). However, the considerable limitation of these studies lies in the lack of representativeness, completeness, and reliability in examining students at a Vietnamese university. As a result, the purpose of the study is to conduct a broad empirical test by using quantitative and qualitative methodologies to assess the academic success of students from different universities in Vietnam and to identify its determinants.

\section{Literature Review}

Although students' success is always among the most popular topic in education for many researchers, its definition is regarded as amorphousness and lacking clarity (Kuh et al., 2006). Hence, it is usually narrowed down to an academic perspective and is known as an academic success (Kuh et al., 2006). Many pieces of evidence have shown that, compared to those with no academic successes, students who have good degrees or higher educational attainment are more likely to be employed with higher salaries (National Center for Education Statistics, 2001). Consequently, students with academic success would enjoy more opportunities to realize their occupational aspirations than those with lower degrees of educational achievements. Besides, those who are equipped with a robust foundation of knowledge are more likely to possess the ability to meet the future demand for 
professional skills and aptitude (Brown \& Burkhardt, 1999). Academic success is defined as the ability and endeavor of students to manage both academic and societal demands, to have a desire to be successful, and to be considered as socially proficient, intrinsically motivated, and goal-oriented (Ellis \& Worthington, 1994).

In the second approach of evaluating student success, we investigate students' second-language proficiency, one of the most vital skills that are essential for students at a time of international integration. Jack Ma, a self-made Chinese billionaire with a humble beginning, emphasized that 'concentrating on learning English very soon is the best decision of my life' since English is the most popular language in the world with 1,132 million speakers (Ghosh, 2020). Therefore, in the period of international integration, big corporations expanding their market into the world always look for candidates who are fluent in English. Especially for multinational corporations with a labor workforce from around the world, English, which plays a role as a common language, is extremely important. As a result, its teaching as a foreign or second language throughout the world is given great emphasis (Emir, 2010). Pennycook (1994) pointed out that any country that wants to gain power and prestige must be proficient in an international language. It is stated that by studying English, even though it is not the daily medium of communication (Grubbs et al., 2009), it enables students from universities all over the world to compete in the global economy. However, student's competency in English has not greatly improved since the research by Nor Hashimah et al. (2008), who have shown that Malaysian graduates are found to be still not proficient in English after about 11 years of learning.

The ultimate determinant of students' success considered in this research is student engagement in both academic and social activities, which has been the epicenter of higher education research for decades (Astin, 1993, 1997; Pascarella \& Terenzini, 1991, 2005). Kuh (2003) has defined engagement as "the time and energy students devote to educationally sound activities inside and outside of the classroom and the policies and practices that institutions use to induce students to take part in these activities." Therefore, student engagement in this research is measured by the award that students receive for both academic and social activities. Educationally purposeful activities, which are also considered as student engagement, have been stated as the core factor in student learning and other impressive results in higher education (Astin, 1993, 1997; Hu \& Kuh, 2002; Pascarella \& Terenzini, 1991, 2005). Supporting the above concept, Shulman (2002) has posited that student engagements in educationally purposeful activities are meaningful and desirable outcomes and also the key elements in students' success in college.

Many studies have separated factors that affect students' success in four groups: psychological-related factors, home environment factors, student demographic factors, and school environment factors. Regarding psychological perspective, self-efficacy perceived behavioral control, attitude, persistence, cognitive complexity, and study habit are considered as the main indicators that strongly influence the students' academic success (Hendricks, 1997; Bandura, 1997). Rabideau (2005) has explained that personal motivation is the driving force behind students' directions, desires, and life ambitions. Also, self-efficacy (SE), an individual's judgment of students' capabilities to organize and execute action plans, is an important character that helps students achieve their desired performances (Bandura, 1997). It was noted that if students engage in learning behaviors with a clear intrinsic goal, they will succeed more and perform better in tests than those who engage without a fundamental goal (Vansteenkiste et al., 2004). This implies that students' psychological indicators play an important role in determining academic successes.

Further, from psychological factors, home environment perspectives indicating family education, familial conditions, and parental encouragement can also influence students' academic attainment (Shahzadi \& Ahmad, 2011). Most of the previous studies assert that parents positively affect their children's learning because family tradition generates utility for all its members as a production unit (Becker \& Tomes, 1976). Shahzadi and Ahmad (2011) point out that the home environment has an enormous impact on students' psychological, emotional, and social status. Based on Becker and Tomes' ideas, Ermisch and Francesconi (2001) show that if, as children, individuals live in single-parent households, they would have a significantly lower level of attainment, defined as the number of years of schooling, than their two-parent-household counterparts. Furthermore, parental socio-economic status is closely related to students' academic performance because parents with higher income may support their children's education better than those with modest salaries (Abdu-Raheem, 2015). Moreover, because the parental expectation is translated into positive energy that increases students' self-improvement and self-esteem (Schneider \& Lee, 1990), it can be said that the relationship between home environment and student success has existed apparently.

In conclusion, most of the previous research has focused on evaluating and measuring academic achievement through scores at school representing as GPA. However, it is a partial judgment to conclude that GPA is the only driver factor of academic achievement because other interpersonal skills such as language proficiency play a vital role in shaping the success of students nowadays. Besides, most studies are conducted in developed countries where the education system and home environment are far different from that of Vietnam. In Vietnam, a few studies were conducted to find out the determinants of academic achievement and 
student success. Tran (2014) shows the effect of cooperative learning on students' achievement and knowledge retention, indicating the effectiveness of cooperation on student success. Behrman and Knowles (1999) conduct a study to examine the associations between household income and children's school success in Vietnam. They conclude that these associations are considerable. Thus, this study will solve these problems mentioned in previous studies by evaluating the impact of indicators on the academic success of students in Vietnam in terms of learning objective (GPA), acquisition skills (English language proficiency), individual factors, and environmental factors collected in the eight most prestigious universities in Vietnam.

\section{Hypothesis and Research Methodology}

\subsection{Hypothesis}

To assess and evaluate the impact of four different driver factors on student success, the paper focuses on building four research hypotheses, corresponding to four different independent variables presented in the models.

H1: Psychological perspective factor has a positive correlation with student success.

As a science, psychology is about the human mind and its wide-ranging functions. Based on Taylor (1999), we assume that the psychological perspective's components imply selfefficacy, perceived behavioral control, attitude, persistence, cognitive complexity, and study habit. Taylor (1999) indicates that perceived behavioral control is responsible for promoting personal development and helps students build personal recognition reflection, thereby serving students to find directions in learning and growth. Despite measuring in different ways, Honicke and Broadbent (2016) and Lane and Lane (2001) indicate that self-efficacy is moderately correlated with academic performance. Furthermore, Turner et al. (2009) explore that higher academic self-efficacy is one reason behind the higher GPA. They emphasize that the more capable students feel about achieving academic achievement in their studies, the more academically successful they might achieve. This illustrates a process of achievement consistently improving in that the more a student performs, the more assured they will become of success in the future. Therefore, all factors related to psychological perspective are expected to have a positive relationship with human capital quality.

H2: The home environment is positively correlated with student success.

ShahzadiandAhmad(2011)show that thehomeenvironment has a great influence on the students' psychological, emotional, and social state. As for home environment variables including parents' educational status and parental level of income, Abdu-Raheem (2015) shows that parental condition is closely related with student academic performance, which is affected by their parent socio-economic, as parents with higher income may take full responsibility for their children's education compared to those with modest wages. Moreover, Schneid and Lee (1990) indicate that parental expectations are the most powerful indicator to predict student academic performance because it is converted to positive energy, increasing selfimprovement, and self-esteem of students. In contrast, other studies on African Americans show that parental expectation was measured according to how well the parent perceived the child was doing in school, would not significantly predict academic performance. Thus, by establishing education promotion funds from a government or big organizations as well as actively promoting parents' awareness of how to raise children is expected to have a positive relation to academic performance.

H3. The school environment directly impacts student success.

In this study, we refer the school environment to different course programs in Vietnam's tertiary, including basic programs, advanced programs, and international programs. Regarding basic programs, Quyen (2018) claims that highquality teachers, a great diversity of races cultures, and low tuition fees, are common benefits of student enrollment in this program. However, larger class size often makes it difficult for the student to receive one-on-one assistance, which means that student must make massive efforts with a spirit of self-discipline in learning (Tucker, 2018). As for advanced programs and international programs, the quality degree of these students is enhanced and more widely recognized at the globe level by training and learning in an international programs (National Database of Legal Documents, 2014). In contrast, learning in English requires students in international and advanced programs to have an advanced English proficiency level. The disadvantage is the high tuition fee (Nguyen \& Ngo, 2007). Therefore, each program, with its pros and cons, can influence student's success differently.

H4: Student demographics are associated with student success.

Alhajraf and Alasfour (2014); Peiperl and Trevelyan (1997); Guney (2009); Sarwar and Sarwar (2012) point out that age or gender have a tremendous impact on academic performance, thereby having a great interaction with student success in term of attainment of learning objectives. Because students become more disciplined when they get older and, thus, achieve higher marks than their younger 
colleagues, furthermore, a research conducted by Gammie et al. (2003) explores that having effective study patterns as well as rational organization skills to cope with pressures on the time can explain why females students outperform their male counterparts in academic success. As for religious affiliation, Li and Murphy (2018)highlight a positive interaction between academic performance and religious affiliation, specifically Christianity. Sharing the same viewpoint, Byfield (2008) suggests that religion can provide students with a wealth of capital as well as an abundant source of cultural capital that they used to their academic advantages. Thus, all factors related to student demographics are expected to have a relationship with student success.

\subsection{Research Models}

To consider and justify the effects of four different independent variables on personal development, earlier studies usually followed the method of quantitative research into the correlation and regression model with assistance from the software. Therefore, in this research, the authors will follow the method of quantitative research into regression models with four independent variables: student demographic, student environment, home environment, and psychological perspective, with the assistance of IBM - SPSS 22. Two different models with three different dependent variables are built in the following models:

$$
\begin{aligned}
\text { Model 1: } A L O= & \alpha \times \beta_{1} \times P S Y+\beta_{2} \times H E M+\beta_{3} \times S T D \\
& +\beta_{4} \times S T E+\varepsilon . \\
\text { Model 2: } A S C= & \alpha \times \beta_{1} \times P S Y+\beta_{2} \times H E M+\beta_{3} \times S T D \\
& +\beta_{4} \times S T E+\varepsilon . \\
\text { Model 3: } E N G= & \alpha \times \beta_{1} \times P S Y+\beta_{2} \times H E M+\beta_{3} \times S T D \\
& +\beta_{4} \times S T E+\varepsilon .
\end{aligned}
$$

\begin{tabular}{|c|c|c|c|c|}
\hline Variables & Meaning & Determined by & Role & Model \\
\hline ALO & $\begin{array}{l}\text { Attainment of learning } \\
\text { objectives }\end{array}$ & GPA & Dependent variable & ALO \\
\hline ASC & $\begin{array}{l}\text { Acquisition of skills and } \\
\text { competencies }\end{array}$ & IELTS & Dependent variable & ASC \\
\hline \multirow{2}{*}{ ENG } & \multirow{2}{*}{ Student engagement } & Academic achievements & Dependent variable & ENG1 \\
\hline & & Social achievements & Dependent variable & ENG2 \\
\hline \multirow{6}{*}{ PSY } & \multirow{6}{*}{ Psychological Perspective } & Self - efficacy & Independent variable & $\mathrm{PSY}_{1}$ \\
\hline & & Perceived-behavioral control & Independent variable & $\mathrm{PSY}_{2}$ \\
\hline & & Attitude & Independent variable & $\mathrm{PSY}_{3}$ \\
\hline & & Persistence & Independent variable & $\mathrm{PSY}_{4}$ \\
\hline & & Cognitive complexity & Independent variable & $\mathrm{PSY}_{5}$ \\
\hline & & Study habit & Independent variable & $\mathrm{PSY}_{6}$ \\
\hline \multirow{5}{*}{ HEM } & \multirow{5}{*}{ Home Environment } & Family education & Independent variable & $\mathrm{HEM}_{1}$ \\
\hline & & Family's condition & Independent variable & $\mathrm{HEM}_{2}$ \\
\hline & & Parental encouragement & Independent variable & $\mathrm{HEM}_{3}$ \\
\hline & & Educational expectation & Independent variable & $\mathrm{HEM}_{4}$ \\
\hline & & Occupational expectation & Independent variable & $\mathrm{HEM}_{5}$ \\
\hline \multirow{5}{*}{ STD } & \multirow{5}{*}{ Student Demographic } & Age & Independent variable & STD $_{1}$ \\
\hline & & Gender & Independent variable & $\mathrm{STD}_{2}$ \\
\hline & & Work experience & Independent variable & $\mathrm{STD}_{3}$ \\
\hline & & Religion & Independent variable & $\mathrm{STD}_{4}$ \\
\hline & & Ethnicity & Independent variable & $\mathrm{STD}_{5}$ \\
\hline \multirow{3}{*}{ STE } & \multirow{3}{*}{ School Environment } & Basic Program & Control variable & STE $_{1}$ \\
\hline & & International Program & Control variable & STE $_{2}$ \\
\hline & & Advance Program & Control variable & $\mathrm{STE}_{3}$ \\
\hline
\end{tabular}

The meaning and role of different variables are as follow:

Table 1: List of dependents, independent and control variables of the regression models 


\subsection{Research Method}

We choose the high-rank multidisciplinary university in Vietnam, based on data from Webometrics Ranking of World Universities (2020), with a wide range of majors such as economics (\#13 National Economics University,
\#47 Banking Academy, \#48 Foreign Trade University, \#68 Academy of Finance and Accounting, \#103 Thuong Mai University), biology, science and technology (\#2 Hanoi University of Science and Technology), law (\#77 Hanoi University of Law), and education (\#1 Vietnam National University Hanoi).

Table 2: Research samples

\begin{tabular}{|c|c|c|c|c|}
\hline University & Type & No. of student & Total & Percent \\
\hline \multirow{5}{*}{$\begin{array}{l}\text { National Economics University } \\
\text { (NEU) }\end{array}$} & Graduated & 22 & \multirow[t]{5}{*}{504} & $4 \%$ \\
\hline & Freshman & 234 & & $46 \%$ \\
\hline & Junior & 129 & & $26 \%$ \\
\hline & Sophomore & 83 & & $16 \%$ \\
\hline & Senior & 36 & & $8 \%$ \\
\hline \multirow{5}{*}{ Foreign Trade University (FTU) } & Graduated & 34 & \multirow{5}{*}{240} & $14 \%$ \\
\hline & Freshman & 74 & & $31 \%$ \\
\hline & Junior & 28 & & $12 \%$ \\
\hline & Sophomore & 42 & & $18 \%$ \\
\hline & Senior & 62 & & $25 \%$ \\
\hline \multirow[t]{5}{*}{ Thuong Mai University (TMU) } & Graduated & 63 & \multirow[t]{5}{*}{336} & $19 \%$ \\
\hline & Freshman & 21 & & $6 \%$ \\
\hline & Junior & 51 & & $15 \%$ \\
\hline & Sophomore & 89 & & $26 \%$ \\
\hline & Senior & 112 & & $34 \%$ \\
\hline \multirow[t]{5}{*}{ Banking Academy (BA) } & Graduated & 13 & \multirow[t]{5}{*}{207} & $6 \%$ \\
\hline & Freshman & 61 & & $29 \%$ \\
\hline & Junior & 90 & & $43 \%$ \\
\hline & Sophomore & 34 & & $16 \%$ \\
\hline & Senior & 9 & & $6 \%$ \\
\hline \multirow[t]{5}{*}{ Academy of Finance (BA) } & Graduated & 47 & \multirow[t]{5}{*}{275} & $17 \%$ \\
\hline & Freshman & 84 & & $31 \%$ \\
\hline & Junior & 99 & & $36 \%$ \\
\hline & Sophomore & 6 & & $2 \%$ \\
\hline & Senior & 39 & & $14 \%$ \\
\hline \multirow[t]{5}{*}{ Law University (HLU) } & Graduated & 26 & \multirow[t]{5}{*}{260} & $10 \%$ \\
\hline & Freshman & 78 & & $30 \%$ \\
\hline & Junior & 52 & & $20 \%$ \\
\hline & Sophomore & 52 & & $20 \%$ \\
\hline & Senior & 52 & & $20 \%$ \\
\hline \multirow{5}{*}{$\begin{array}{l}\text { University of science and } \\
\text { technology (HUST) }\end{array}$} & Graduated & 16 & \multirow[t]{5}{*}{301} & $5 \%$ \\
\hline & Freshman & 111 & & $37 \%$ \\
\hline & Junior & 109 & & $36 \%$ \\
\hline & Sophomore & 44 & & $15 \%$ \\
\hline & Senior & 21 & & $7 \%$ \\
\hline \multirow[t]{5}{*}{ National University (VNU) } & Graduated & 130 & \multirow[t]{5}{*}{419} & $31 \%$ \\
\hline & Freshman & 70 & & $17 \%$ \\
\hline & Junior & 45 & & $11 \%$ \\
\hline & Sophomore & 65 & & $16 \%$ \\
\hline & Senior & 109 & & $25 \%$ \\
\hline Total & & 2542 & 2542 & $100 \%$ \\
\hline
\end{tabular}


Primary research data were collected from our questionnaire. This questionnaire was sent randomly to more than 400 students per chosen university, including freshman, sophomore, junior, senior, and alumni. Furthermore, we also interview students form these schools to find out rational evaluation criteria for ensuring reliability, transparency, and accuracy. With the questionnaires given out at eight different universities, we conducted 2,542 observations to get the best estimate. On that basis, a regression model is set up for analysis and verification with the help of specialized software such as SPSS 22 and STATA 2016.

\section{Research Results}

\subsection{Descriptive Analysis}

The table illustrate the detailed statistical results of three different dependent variables (ALO, ASC, ENG) and two different independent variables (HEM, PSY) with their minimum, maximum, sum, mean, standard deviation and variance calculated from 2,542 respondents. For the dependent variables, the results indicate that ALO has the highest mean (2.88), which is 1.02 higher than ASC (1.86) and 1.201 higher than ENG (1.679). Thus, it is clear to say that most of the economic students in Vietnam have a good Grade Point Average (GPA). At the same time, their English proficiency and engagement in activities are still limited, resulting in a quite low level.

Figure 1 illustrates the variety of IELTS scores of students from eight high-ranking economic universities mentioned above in Vietnam. Overall, the differences among scores are significant in eight universities. Most respondents have an IELTS score under 5 in all universities, except TMU and HLU. On the contrary, students have scored from 8 to 9 , accounting for the lowest numbers in all the universities. VNU has the highest number of students having a score under 5, fivefold higher than those of HLU, which is the lowest figure, about 40, among the eight universities. There are remarkable variations between HLU and other universities when it comes to respondents with a score from 7-8, approximately 50, 45, 45, 40, 38, 25, 23, respectively.

Figure 2 illustrates five different education levels, including excellent, good, fair, average, and weak, from eight famous economic universities in Vietnam. Overall, NEU has the highest figure of excellent students and good students, which is replaced by VNU in fair and average students, but HUST in under average one. On the other hand, $\mathrm{AOF}$ is on the reserve pattern with the lowest number of weak students, which is replaced by BA in excellent students, but VNU in good students while FTU and HLU in average and fair students, respectively. With regards to the excellent level at eight chosen universities, it accounted for 30 for NEU, 20 for VNU, and FTU, showing moderately higher than the figures for the other universities. Similarly, good students made up 105 for HLU, which is appropriately 60 lower than the figure for NEU, but 20 higher than that for both AOF and FTU. By contrast, VNU, NEU, TMU have more positive feedbacks than negative feedbacks in fair and average in comparison with that of AOF, BA, FTU, HUST. However, HLU is on the reserve pattern with more negative feedback than positive feedbacks in fairness. The differences between HUST, which had the highest number of 96, and other universities, on the other hand, in terms of weak students, are most considerable.

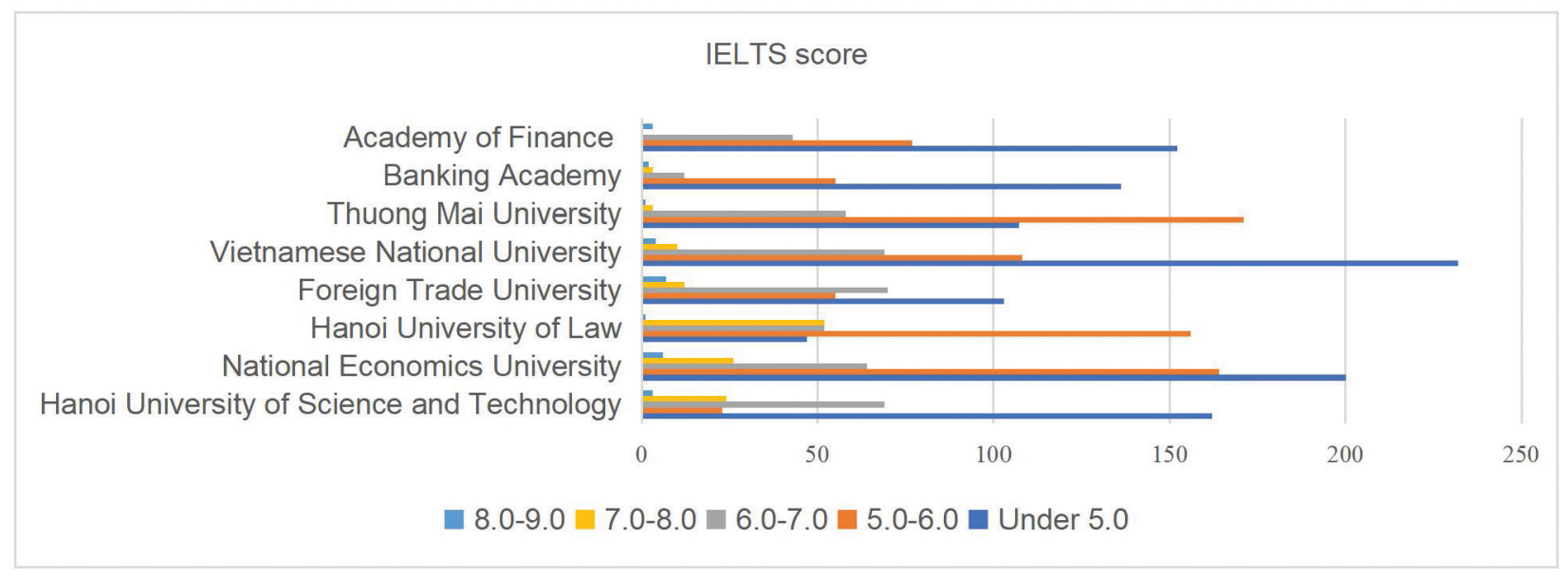

Figure 1: Students' IELTS score 


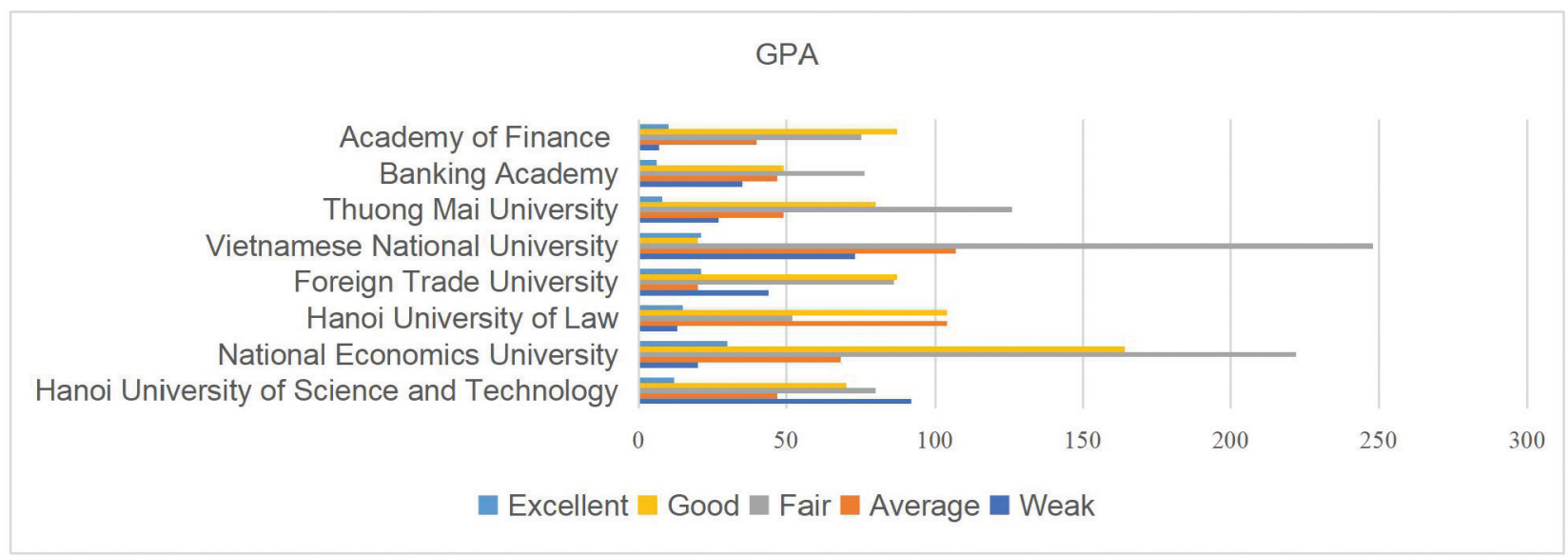

Figure 2: Students' GPA
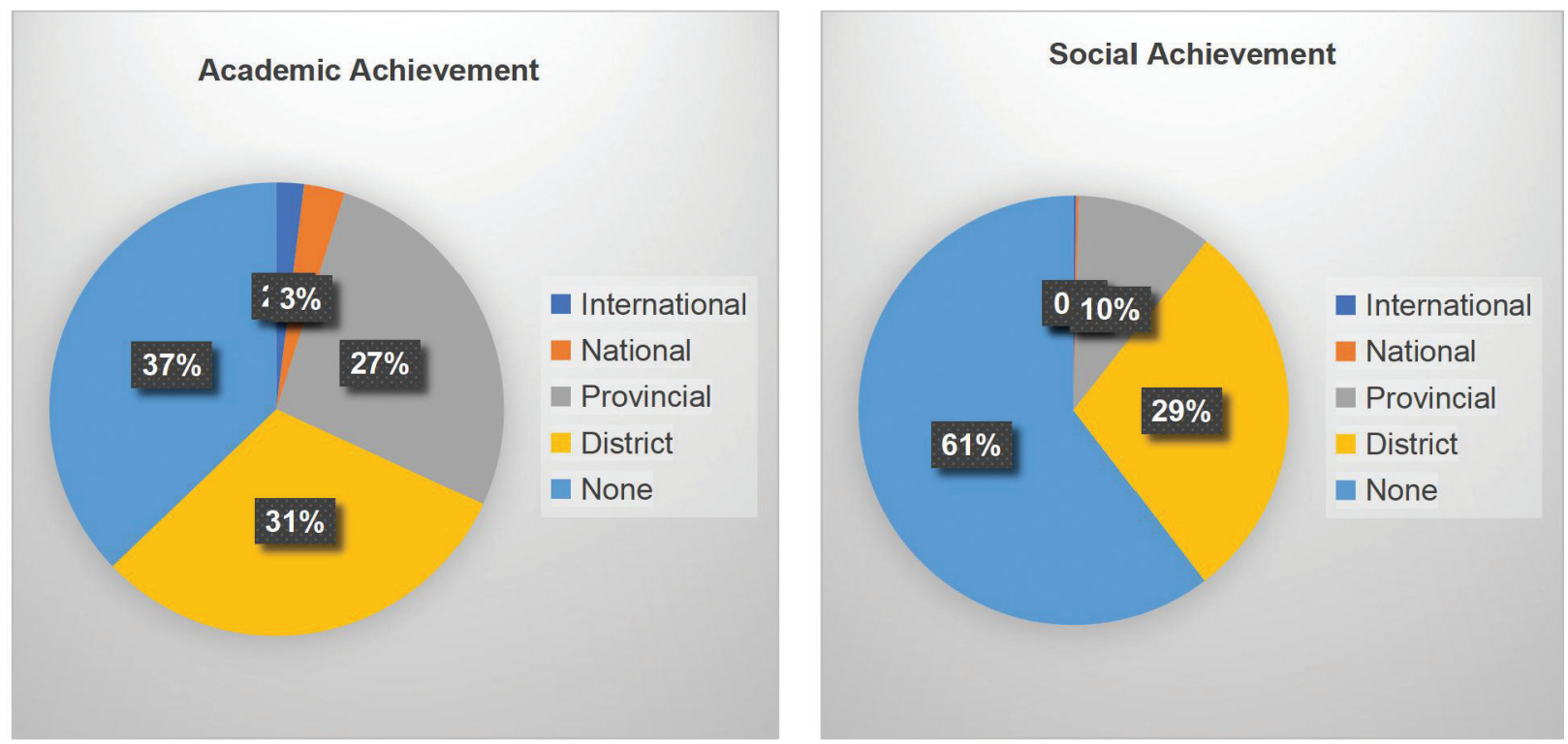

Figure 3: Academic achievement and social achievement

The pie charts illustrate the percentage of, not only academic achievement, but also social accomplishment in five different grades, including international, national, provincial, district grade, and none of them. In general, a lot of students in Vietnam do not get any awards in both academic or social competitions, accounting for the highest percentage in both charts, with $37 \%$ and $61 \%$, respectively. Because the percentage of students with no prize in social activities is near twice as much as that of students with no prize in academic activities, it can be said that students in Vietnam tend to involve themselves in academic activities rather than social activities.
In the first pie chart, which describes the academic ground up to $37 \%$ of the achievement, is not made in a specific grade, which tops the list of five grades. District achievement accounted for almost one-third of the total, followed by provincial accomplishment with $27 \%$. There are only $3 \%$ of the national achievement grade, and $2 \%$ of them are made internationally.

As for the social domain, it seems that many students do not get any awards. This number is the highest among the five grades, with more than $60 \%$ in total. District achievement came second in the list with $29 \%$, while provincial one only accounted for $10 \%$. Different from the academic field, there is even no accomplishment in both international and national grades. 


\subsection{Measuring Reliability}

For PSY variables, the test results show that Cronbach's Alpha coefficient if Item deleted of the PSY4 variable is higher than Cronbach's Alpha coefficient $=0.862$. Therefore, the PSY4 variable is removed from the model to raise The Cronbach's Alpha reliability coefficient of the PSY variable. Continuing to perform the reliability test of remaining variables using the Cronbach's Alpha scale, the test results illustrate that the observed variables PSY have an appropriate correlation coefficient of total variables $(\geq 0.3$ ). As the Cronbach's Alpha coefficient $=0.863 \geq 0.8$, so variables PSY1, PSY2, PSY3, and PSY5 meet reliability requirements, and they are very good measurement scales for PSY.

Regarding HEM variables, the test results indicate that Cronbach's Alpha coefficient if Item deleted of HEM4, HEM5 variables is greater than Cronbach's Alpha coefficient $=0.573$, and Corrected Item of HEM3, HEM4, and HEM5 is less than 0.3. Hence, HEM3, HEM4, and HEM5 variables are removed from the HEM variable to increase the reliability of the scale. All the remaining HEM variables, using the Cronbach's Alpha scale, continue to be performed, and the results show that Cronbach's Alpha coefficient if Item deleted of HEM6, is greater than Cronbach's Alpha coefficient $=0.760$. So HEM6 variable is eliminated from the model. After these above steps, there are two variables left, including HEM1 and HEM2 in the HEM variable.

\subsection{Analysis of Discovery Factors EFA}

The analysis of the EFA discovering factors shows that $0.5<\mathrm{KMO}$ coefficient $=0.734<1,000$, which means the analysis of the factors is consistent with the research data set. Besides, the Sig of Bartlett's Test of Sphericity $(=0)$ is less than 0.05 . Consequently, this result proves the correlation between observed variables in the same factor.

The analysis of the independent variables included in the model indicates two factors extracted at Eigenvalue: 1,720. Relying on Eigenvalue criteria one or more, we stop at the second factor since the Eigenvalue of the third factor is 0.451 $<1$. Therefore, if we rely on Eigenvalue criteria one or more, we stop at the third factor. Also, because the total variance explained $=76.040 \%>50 \%$ shows, the EFA model is suitable. Thus, the two extracted factors will explain 76.040 $\%$ of the variability of the observations.

\subsection{Correlation Analysis}

The results from the correlation analysis show that the correlation of the dependent variables, including ALO, ASC, and ENG, is at a low level (0.308). The same goes for almost all the independent variables apart from HEM and Learning year, experience with 0.692 and 0.826 . So, it can be said that the multi-collinear phenomenon among independent variables would be likely not to occur. At the next steps, we will examine the multi-collinear phenomenon among these independent variables more closely. Furthermore, the table shows that there is no linear relationship between ALO and Learning year or gender while the other independent variables, but the program has negative influences on ALO. It can be seen in the table that Learning year and experience have no relation to ASC as the sig. is higher than 0.05 . The remaining variables, except for Ethnicity and Program variables, positively affect the ASC variable. For the last dependent variable, ENG is not impacted by Learning year and gender but positively affected by PSY, HEM, Experience, Religion, Ethnicity, and negatively impacted by the program.

\subsection{Regression Model}

Table 3 shows the regression results of the independent and dependent variables in the three models. Going deeper into the ALO model (column 2), we see that all independent variables are statistically significant and positively correlate with the student's GPA. In terms of signs of the impact, the home environment and psychological perspective all have a positive impact on the grade point average of students with a confidence level of $99 \%$. Besides, the result points out that the number of students studying in the basic program has a lower GPA than that of students studying in advanced $\&$ international programs, accounting for $8.02 \%$ with a confidence level of $99 \%$.

Additionally, the female students had higher $(1,85 \%)$ average GPA scores than male students; besides, it also demonstrates that the older students are expected to achieve 0.0303 GPA scores higher than young students at the 0.05 level. Next is the work experience factors. For each more year of working experience, students' GPA will increase by $0,516 \%$ with a confidence level of $95 \%$. In particular, the result shows that non-religious students tend to get a $7.18 \%$ better GPA than religious students, and Kinh students have $6.08 \%$ better grades than those in minority ethnicity. Thus, model 1 can be written as follows:

$$
\begin{aligned}
& \text { ALO model: } \\
& \begin{aligned}
\text { ALO }= & 0.910+0.078 \times H E M+0.536 \times P S Y-0.401 \\
& \times S T E-0.03 \times S T D_{1}-0.09 \times S T D_{2}+0.02 \\
& \times S T D_{3}+0.304 \times S T D_{5}+\varepsilon .
\end{aligned}
\end{aligned}
$$

Model 2 shows the link between eight independent variables, including home environment, psychological perspective, school program, schoolyears, gender, work experience, religion, ethnicity, and dependent variables 
illustrating the student's IELTS score. While STD1 (school years) and STD3 (work experience), both of these control variables seem to be not relevant to IELTS scores, HEM (home environment) and PSY (psychological perspective), on the other hand, has a positive and significant correlation with IELTS scores with a confidence level of $99 \%$. Students learning at advanced and international programs can achieve 0.475 IELTS scores higher than those learning at basic programs. Regarding the students' demographic factors, including STD4 (Religion) and STD5 (Ethnicity), they have a significant impact on IELTS scores. In detail, the results show that non-religious students seem to get $15.76 \%$ better IELTS score than religious students at the 0.01 level. In contrast, Kinh students are observed to achieve lower IELTS scores than those in minority ethnicity, accounted for 3.08\% at the confidence level of $95 \%$. Therefore, model 2 can be written as follows:

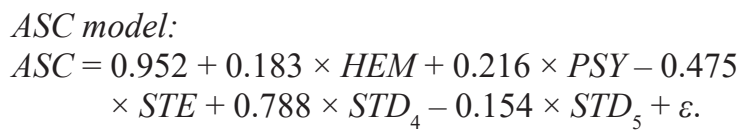

Looking specifically at model 3, we see the relationship between theindependent variables, including homeenvironment, psychological perspective, school program, schoolyears, gender, work experience, religion, ethnicity, and dependent variables showing through student engagement. The table indicates that PSY and HEM have a significant and positive correlation with ENG, while STE and STD1 variables negatively affect dependent variables at a statistical significance of $99 \%$. As for students' demographic, including gender, work experience, religion, and ethnicity, gender variables (STD2) seem to be irrelevant to the student engagement; however, student religion (STD4) and student ethnicity (STD5) have a significant and positive correlation, but student working experience (STD3) slightly and positively impact on achievement competition of students (ENG) with the confidence level of $99 \%$. Hence model 3 can be written as follows:

$$
\begin{aligned}
& E N G \text { model: } \\
& \begin{aligned}
E N G= & 0.739+0.07 \times H E M+0.177 \times P S Y-0.118 \\
& \times S T E-0.023 \times S T D_{1}+0.05 \times S T D_{3}+0.344 \\
& \times S T D_{4}+0.141 \times S T D_{5}+\varepsilon .
\end{aligned}
\end{aligned}
$$

\begin{tabular}{|c|c|c|c|}
\hline & $(1)$ & $(2)$ & (3) \\
\hline Variables & ALO & ASC & ENG \\
\hline \multirow[t]{2}{*}{ HEM (Home Environment) } & $0.0779^{* * *}$ & $0.183^{* * *}$ & $0.0701^{* * *}$ \\
\hline & $(0.0200)$ & $(0.0196)$ & $(0.0133)$ \\
\hline \multirow[t]{2}{*}{ PSY (Psychological Perspective) } & $0.536^{* * *}$ & $0.216^{* * *}$ & $0.177^{* * *}$ \\
\hline & $(0.0219)$ & $(0.0215)$ & $(0.0146)$ \\
\hline \multirow[t]{2}{*}{ STE (Program) } & $-0.401^{* * *}$ & $-0.475^{\star * \star}$ & $-0.118^{\star * *}$ \\
\hline & $(0.0431)$ & $(0.0422)$ & $(0.0287)$ \\
\hline \multirow[t]{2}{*}{$\mathrm{STD}_{1}$ (Schoolyear) } & $-0.0303^{* *}$ & 0.00319 & $-0.0229^{* * *}$ \\
\hline & $(0.0127)$ & $(0.0125)$ & $(0.00849)$ \\
\hline \multirow[t]{2}{*}{$\mathrm{STD}_{2}$ (Gender) } & $-0.0925^{\star *}$ & $0.296^{* \star \star}$ & -0.0378 \\
\hline & $(0.0430)$ & $(0.0421)$ & $(0.0286)$ \\
\hline \multirow[t]{2}{*}{$\mathrm{STD}_{3}$ (Work experience) } & $0.0258^{* *}$ & -0.0118 & $0.0511^{* * *}$ \\
\hline & $(0.0101)$ & $(0.00988)$ & $(0.00672)$ \\
\hline \multirow[t]{2}{*}{$\mathrm{STD}_{4}$ (Religion) } & $0.359^{* * *}$ & $0.788^{* * *}$ & $0.344^{* * *}$ \\
\hline & $(0.0836)$ & $(0.0819)$ & $(0.0557)$ \\
\hline \multirow[t]{2}{*}{$\mathrm{STD}_{5}$ (Ethnicity) } & $0.304^{* * *}$ & $-0.154^{\star \star}$ & $0.141^{* * *}$ \\
\hline & $(0.0722)$ & $(0.0707)$ & $(0.0481)$ \\
\hline \multirow[t]{2}{*}{ Constant } & $0.910^{* * *}$ & $0.952^{* \star *}$ & $0.739^{* * *}$ \\
\hline & $(0.137)$ & $(0.134)$ & $(0.0913)$ \\
\hline Observations & 2,542 & 2,542 & 2,542 \\
\hline R-squared & 0.248 & 0.187 & 0.117 \\
\hline
\end{tabular}

Table 3: Regression analysis

Standard errors in parentheses. ${ }^{* * *} p<0.01,{ }^{* *} p<0.05,{ }^{*} p<0.1$ 


\section{Conclusions}

Students' success, which is also known as academic success, is assessed based on the attainment of learning objectives (GPA), acquisition of skills, competencies (IELTS score), and student achievement. Therefore, students' success is thoroughly and accurately evaluated. From the results, there are many factors such as the student's home environment, student's psychological perspective, school programs, and student demographic that affect student's academic achievement. In conclusion, students' success level varies between student to student that the level depends on the rank of factors shown in the results.

Based on the findings of this study, researchers have come out with several recommendations to overcome the limitations and obtain a better result for further research. Firstly, the study only looks at three dimensions of academic performance, namely, Grade Point Average (GPA), International English Language Testing System Score (IELTS score), and student engagement, which means this leads to a biased result without concerning some critical indicators such as career success, satisfaction, or persistence. Therefore, future research could expand the definition of students' success by determining the goals and personal situation of each student, because the definition of student s' success, especially academic success, is necessarily complex and broad (York et al., 2015).

\section{References}

Abdu-Raheem, B. (2015). Parents' Socio-Economic Status as Predictor of Secondary School Students'Academic Performance in Ekiti State, Nigeria. Journal of Education and Practice, 6(1), 123-128. Retrieved from https://eric.ed.gov/?id=EJ1083795

Addow, A. M., Abubakar, A. H., \& Abukar, M. S. (2013). English Language Proficiency and Academic Achievement for Undergraduate Students in Somalia. Educational Research International, 2(2), 59-66.

Alhajraf, N. M., \& Alasfour,A. M. (2014). The Impact of Demographic and Academic Characteristics on Academic Performance. International Business Research, 7(4), 92-100. Canadian Center for Business Education. doi:10.5539/ibr.v7n2p92

Ali, N., Jusoff, K., Ali, S., Mokhtar, N., \& Salamat, A. S. (2009). The Factors Influencing Students' Performance at Universiti Teknologi MARA Kedah, Malaysia. Management Science and Engineering, 3(4), 81-90. doi:https://doi.org/10.3968/j. mse.1913035X20090304.010

Aljaaidis, K. S., Bagais, O. A., \& Al-Moataz, E. (2020). Knowledge sharing and individuals' effectiveness in educational institutions. Management Science Letters, 10(15), 3477-3484. doi:10.5267/j.msl.2020.7.001

Amaliyah, S., Anwar, K., \& Nuqul, F. L. (2017). The Effect of Religious Identity toward Academic Performance: An
Experimental Study. In: 6th Annual International Conference on Cognitive and Behavioral Psychology (pp. 26-29). Singapura. doi:10.5176/2251-1865 CBP17

Astin, A. W. (1993). Assessment for Excellence: The Philosophy and Practice of Assessment and Evaluation in Higher Education. American Council on Education/Macmillan Series on Higher Education. New York, NY: Macmillan Publishing Co.

Astin, A. W. (1997). What Matters in College: Four Critical Years Revisited (1st ed.). San Francisco, CA: Jossey-Bass.

Bandura, A. (1997). Self-Efficacy: The exercise of control. New York, NY: W H Freeman/Times Books/ Henry Holt \& Co.

Bean, J., \& Eaton, S. B. (2002). The Psychology Underlying Successful Retention Practices. Journal of College Student Retention: Research, Theory and Practice, 3(1), 73-89. doi:https://doi.org/10.2190/6R55-4B30-28XG-L8U0

Becker, G., \& Tomes, N. (1976). Child Endowments and the Quantity and Quality of Children. The Journal of Political Economy, 84(4), 143-162. Retrieved from https://www.jstor.org/stable/1831106

Behrman, J., \& Knowles, J. (1999). Household income and child schooling in Vietnam. The World Bank Economic Review, 13(2), 211-256.

Brown, H. E., \& Burkhardt, R. L. (1999). Predicting Student Success: The Relative Impact of Ethnicity, Income, and Parental Education. AIR 1999 Annual Forum Paper.

Busato , V. V., Prins, F. J., Elshout, J. J., \& Hamaker, C. (2000). Intellectual ability, learning style, personality, achievement motivation and academic success of psychology students in higher education. Personality and Individual Differences, 29(6), 1057-1068. doi:https://doi.org/10.1016/S0191-8869(99)00253-6

Byfield, C. (2008). The impact of religion on the educational achievement of Black boys: A UK and USA study. British Journal of Sociology of Education, 29(2), 189-199. https://doi. org/10.1080/01425690701837547

Carnevale, A. P., Smith, N., \& Strohl, J. (2013). Recovery: Job Growth and Education Requirements Through 2020. Washington, DC: Georgetown University. Retrieved from cew. georgetown.edu/recovery 2020

Choi, N. (2005). Self-Efficacy and Self-Concept as Predictors of College Students' Academic Performance. Psychology in the Schools, 42(2), 197-205. doi:https://doi.org/10.1002/pits.20048

Van Dao, D. (2008). Some Vietnamese students' problems with English grammar: A preliminary study. HPU TESL Working Paper Series, 37.

Ellis, E., \& Worthington, L. (1994). Research Synthesis on Effective Teaching Principles and the Design of Quality Tools for Educators. The University of Oregon.

Emir, S. (2010). A Study on the Affective Attitudes of Students at Gazi Educational Faculty towards English Classes. Ekev Academic Review, 14(45), 129.

Englishaccess. (2019, January 17). Englishaccess. Retrieved from Englishaccess: https://englishaccess.co.za/the-7-benefits-oflearning-the-english-language/ 
Ewell, P., \& Wellman, J. (2007). Enhancing Student Success in Education: Summary Report of the NPEC Initiative and National Symposium on Postsecondary Student Success. Retrieved from https://nces.ed.gov/npec/pdf/Ewell_Report.pdf

Fredricks, J. A., Blumenfeld, P. C., \& Paris, A. H. (2004). School Engagement: Potential of the Concept, State of the Evidence. Review of Educational Research, 74(1), 59-109. doi:10.3102/00346543074001059

Freeman, R. (2017). The Relationship Between Extracurricular Activities And Academic Achievement. Retrieved from https:// digitalcommons.nl.edu/diss/245

Fruyt, F. D., \& Mervielde, I. (1996). Personality and interests as predictors of educational streaming and achievement. European Journal of Personality, 10(5), 405-425. doi:10.1002/(SICI)10990984(199612)10:5<405::AID-PER255>3.0.CO;2-M

Ghosh, I. (2020, February 15). Markets Insider. Retrieved from Markets Insider: https://markets.businessinsider.com/news/ stocks/100-most-spoken-languages-1028908456

Goff , M., \& Ackerman, P. L. (1992). Personality-intelligence relations: Assessment of typical intellectual engagement. Journal of Educational Psychology, 84(4), 537-552. https://doi. org/10.1037/0022-0663.84.4.537

Graham, J. G. (1987, September). English Language Proficiency and the Prediction of Academic Success. TESOL Quarterly, 21(3), 505-521. https://doi.org/10.2307/3586500

Green, A. E. (2003, November). Labour Market Trends, Skill Needs and the Ageing of the Workforce: A Challenge for Employability? Local Economy, 18(4), 306-321. https://doi. org/10.1080/0269094032000153835

Grubbs, S., Chaengploy, S., \& Worawong, K. (2009). Grubbs, S. J., ChaengploRajabhat and Traditional Universities: Institutional Differences in Thai Students' Perceptions of English. Higher Education, 57, 283-298. http://dx.doi.org/10.1007/s10734-0089144-2

Guney, Y. (2009). Exogenous and Endogenous Factors Influencing Students' Performance in Undergraduate Accounting Modules. Accounting Education, 18(1), 51-73. https://doi. org/10.1080/09639280701740142

Halamandaris, K. F., \& Power, K. G. (1999). Individual differences, social support and coping with the examination stress: A study of the psychosocial and academic adjustment of first year home students. Personality and Individual Differences, 26(4), 665685. https://doi.org/10.1016/S0191-8869(98)00172-X

Hearn , J. C. (2006, October). Student Success: What Research Suggests for Policy and Practice. Retrieved from https://nces. ed.gov/npec/pdf/synth_Hearn.pdf

Heil, D. K., \& Aleamoni, L. M. (1974). Assessment of the Proficiency in the Use and Understanding of English by Foreign Students as Measured by the Test of English as a Foreign Language. Retrieved from https://eric.ed.gov/?id=ED093948

Hendricks, A. (1997). Predicting student success with the Learning and Study Strategies Inventory (LASSI). Ames, Iowa: Iowa State University.
Hillage, J. (2002). Employers Skill Survey 2002. Jo Regan Institute for Employment Studies. Retrieved from https://dera.ioe. ac.uk/4589/1/RR372.pdf

Honicke, T., \& Broadbent, J. (2016). The influence of academic self-efficacy on academic performance: A systematic review. Educational Research Review, 17, 63-84. http://dx.doi. org/10.1016/j.edurev.2015.11.002

Hu, S., \& Kuh, G. D. (2002). Being (Dis)Engaged in Educationally Purposeful Activities: The Influences of Student and Institutional Characteristics. Research in Higher Education, 43, 555-575. https://doi.org/10.1023/A:1020114231387

Jalaluddin, N., Awal, N., \& Bakar, K. (2008). The Mastery of English Language among Lower Secondary School Students in Malaysia: A Linguistic Analysis. European Journal of Social Sciences, 7(2), 106-119.

Jones, E., \& Jackson, J. (1990). College Grades and Labor Market Rewards. The Journal of Human Resources, 25(2), 253-266. doi: $10.2307 / 145756$

Kaighobadi, M., \& Allen, M. T. (2008). Investigating Academic Success Factors for Undergraduate Business Students. Decision Sciences Journal of Innovative Education, 6(2), 427-436. http:// dx.doi.org/10.1111/j.1540-4609.2008.00184.x

Kim, J.-E. (2019). The Impact of Creative Role Identity and Creative Self-Efficacy on Employee Creativity in the Hotel Business. Journal of Asian Finance, Economics and Business, 6(2), 123-133. https://doi.org/10.13106/jafeb.2019.vol6.no2.123

Kiriakidis, P., Decosta, J. W., \& Sandu, A. (2011). What is the effect of grade point average (GPA) on courses taken either faceto-face or online by undergraduate working adult students? Revista de Cercetare Si Interventie Sociala, 33, 7-26. https:// dx.doi.org/10.2139/ssrn.1841084

Kuh, G., Kinzie, J., Buckley, J., Bridges, B., \& Hayek, J. (2006). What Matters to Student Success: A Review of the Literature. In: Commissioned Report for the National Symposium on Postsecondary Student Success: Spearheading a Dialog on Student Success.

Kuh, G. D. (2003). What We're Learning About Student Engagement From NSSE: Benchmarks for Effective Educational Practices. Change: The Magazine of Higher Learning, 24-32. doi:10.1080/00091380309604090

Lane, J., \& Lane, A. (2001). Self-efficacy and Academic Performance. Society for Personality Research, 29(7), 687-694. doi:10.2224/sbp.2001.29.7.687

Le, T. T., \& Pham, T. T. (2018). Some Solutions of State Management over Education in the Social-Economic Market in Social Orientation in Our Country Today. Journal of Education, 115-118.

Li, N., \& Murphy, W. H. (2018). Religious Affiliation, Religiosity, and Academic Performance of University Students: Campus Life Implications for US Universities. Religion \& Education, 45(1), 1-22. https://doi.org/10.1080/15507394.2017.1398561

Lindsay, N. K., Howell, S. L., \& Dwight Laws, R. (2009). Completion Rates and Distance Learners. Encyclopedia of 
Distance Learning, 361-367. https://doi.org/10.4018/978-160566-198-8.ch054

Loury, L. D., \& Garman, D. (1995, April). College Selectivity and Earnings. Journal of Labor Economics, 13(2), 289-308. doi:10.1086/298375

Martirosyan, N. M., Hwang, E., \& Wanjoh, R. (2015). Impact of English Proficiency on Academic Performance of International Students. Journal of International Students, 5(1), 60-71.

Mckinney, A. P., Carlson, K. D., Mecham III, R. L., D’Angelo, N. C., \& Connerley, M. L. (2006). Recruiters' Use of GPA in Initial Screening Decisions: Higher Gpas Don't Always Makethe Cut. Personnel Psychology, 56(4), 823-845. 10.1111/j.17446570.2003.tb00241.x

Ministry of Labour, Invalids and Social Affairs. (2019). Overview of Vietnam Labour Market. Ha Noi: Ministry of Labour, Invalids and Social Affairs. Retrieved from http://molisa.gov. vn/Upload/ThiTruong/LMU-So23-Q32019-final.pdf

National Database of Legal Documents. (2014, July 18). Retrieved from National Database of Legal Documents: http://vbpl.vn/bogiaoducdaotao/Pages/vbpq-van-ban-goc. aspx?ItemID $=46125$

Nguyen, C. B. (2018). Study on The Situation of Factor Affecting The Learning Motivation of Hong Duc University's Students. Journal of Education, 147-150. Retrieved from https:// tapchigiaoduc.moet.gov.vn/vi/magazine/so-dac-biet-thang-6339/31-nghien-cuu-thuc-trang-cac-yeu-to-anh-huong-den-dongco-hoc-tap-cua-sinh-vien-truong-dai-hoc-hong-duc-6114.html

Nguyen, D. T., \& Ngo, L. T. (2007). National School of Education, Hanoi. Retrieved from Dai Hoc Quoc Gia Ha Noi: https://vnu. edu.vn/home/?C1635/N4806/Lien-ket-dao-tao-dai-hoc-quocte:-thach-thuc-va-trien-vong-(Qua-kinh-nghiem-thuc-tien-cuaKhoa-Quoc-te).htm

Nguyen, D. T., Hoang, O. T., \& Le, H. D. (2017). Status and Factors Influencing Study Result of Students form Economic and Business Administration Faculty, Vietnam Forestry University. 134-141. Retrieved from http://vnuf.edu.vn/ documents/4400543/5703735/17.Nguyen.Thuy.Dung.pdf

Nguyen, K. T., Duong, T. M., Tran, N. Y., Ha, A. T., \& Phung, Y. T. (2019). The Impact of Emotional Intelligence on Performance: A Closer Look at Individual and Environmental Factors. The Journal of Asian Finance, Economics and Business, 7(1), 183193. https://doi.org/10.13106/jafeb.2020.vol7.no1.183

Nguyen, T. T. (2016). Formation of The Student' Self-study Skills - An Essential need in the Pedagogical Training. Retrieved from http://tapchikhoahoc.dnpu.edu.vn/UserFiles/Docs/ TapChi/2016/3/2.\%20Nguyen\%20Thanh\%20Thuy_10-16.pdf

Nor Hashimah, J., Norsima, M. A., \& Kesumawat, A. B. ( 2008). The mastery of English language among lower secondary school students in Malaysia: A linguistic analysis. European Journal of Social Sciences, 7(2), 106-119.

Pascarella, E. T., \& Terenzini, P. T. (1991). How College Affects Students: Findings and Insights from Twenty Years of Research. San Francisco, CA: Jossey-Bass.
Pascarella, E. T., \& Terenzini, P. T. (2005). How College Affects Students: A Third Decade of Research. San Francisco, CA: Jossey-Bass.

Pennycook, A. (1994). The Cultural Politics of English as an International Language (1st ed.). London, UK: Routledge.

Phuc, P. T., Vinh, N. Q., \& Do, Q. H. (2020). The implementation of outcome-based education: Evidence from master program in economic management at Hanoi universities. Management Science Letters, 10(14), 3299-3306. doi:10.5267/j. msl.2020.6.008

Pinon, R., \& Haydon, J. (2010). English Language Quantitative Indicators: Cameroon, Nigeria, Rwanda, Bangladesh and Pakistan. A custom report compiled by Euromonitor International for the British Council.

Rabideau, S. (2005). Effects of achievement motivation on behavior. Retrieved from http://www.personalityresearch.org/ papers/rabideau.html

Rahman, S., Mia, M., Ahmed, F., Thongrak, S., \& Kiatpathomchai, S. (2020). Assessing Students' Satisfaction in Public Universities in Bangladesh: An Empirical Study. Journal of Asian Finance, Economics and Business, 7(8), 323-332. https:// doi.org/10.13106/jafeb.2020.vol7.no8.323

Rochelle, C. F., \& Dotterweich, D. (2007). Student Success in Business Statistics. Journal of Economics and Finance Education, 6(1), 19-24.

Sarwar, A., \& Sarwar, M. S. (2012). Factors Having impact on the Performance of Business Students: Case study of Institute of Business and Information Technology (IBIT). International Journal of Business and Social Science, 3(17), 279-293.

Savia Coutinho, S. A. (2007). The relationship between goals, metacognition, and academic success. Educate Journal, 7(1), $39-47$.

Sawe, B. E. (2019, June 7). WorldAtlas. Retrieved from WorldAtlas: https:/www.worldatlas.com/articles/most-popular-languagesin-the-world.html

Schneider, B., \& Lee, Y. (1990). A model for academic success: The school and home environment of East Asian students. Anthropology \& Education Quarterly, 358-377. https://doi. org/10.1525/aeq.1990.21.4.04x0596x

Shahzadi,E., \& Ahmad, Z. (2011). A study on academic performance of university students. In: 8th International Conference on Recent Advances in Statistics (pp. 255-268). Lahore, Pakistan. doi:10.13140/2.1.3949.3126

Shoji, K. (2018, June 18). thejapantimes. Retrieved from thejapantimes: https://www.japantimes.co.jp/life/2018/06/18/ language/japanese-suck-learning-english/

Shulman, L. S. (2002). Making Differences: A Table of Learning. Change: The Magazine of Higher Learning, 6, 36-44. https:// doi.org/10.1080/00091380209605567

T. V. (2019, May 22). giaoducthoidai. Retrieved from giaoducthoidai: https:/giaoducthoidai.vn/gia-dinh/tre-ap-luctruoc-ky-vong-cua-cha-me-giai-phap-nao-thu-hep-khoangcach-4004883-c.html 
Taylor, C. M. (1999). Education and personal development: a reflection. BMJ Journal, 81(6), 531-534. http://dx.doi. org/10.1136/adc.81.6.531

Tran, V. (2014). The Effect of Cooperative Learning on the Academic Achievement and Knowledge Retention. International Journal of Higher Education, 3(2), 131-140. doi:10.5430/ijhe.v3n2p131

Truong, L. D. (2014). Factors influence the development of student knowledge. National Library of Vietnam, Retrieved from http:// nlv.gov.vn/nghiep-vu-thu-vien/mot-so-nhan-to-anh-huong-toiviec-phat-trien-kien-thuc-thong-tin-cho-sinh-vien.html

Tucker, K. (2018, December 5). wehavekids. Retrieved from https:// wehavekids.com/education/schooltypes\#

Turner, E. A., Chandler, M., \& Heffer, R. W. (2009). The Influence of Parenting Styles, Achievement Motivation, and Self-Efficacy on Academic Performance in College Students. Journal of College Student Development, 50(3), 337-346. doi:10.1353/ csd.0.0073

US Department of Education. (2001). The Condition of Education 2001. Retrieved from https://nces.ed.gov/pubs2001/2001072.pdf

United Nations. (2019). The Sustainable Development Goals Report 2019. United Nations.

Vansteenkiste, M., Simons, J., Lens, W., Sheldon , K., \& Deci, E. (2004). Motivating learning, performance, and persistence: the synergistic effects of intrinsic goal contents and autonomysupportive contexts. Journal of Personality and Social Psychology, 87(2), 246-260. doi:10.1037/0022-3514.87.2.246

Vietnam Works. (2019). Online Recruitmen Report. Ha Noi: Vietnam Works. Retrieved from https://www.navigosgroup. $\mathrm{com} / \mathrm{vi} /$ vietnamworks-bao-cao-thi-truong-tuyen-dung-tructuyen-nua-dau-nam-2019-tai-viet-nam/
Vuong, M., Brown-Welty, S., \& Tracz, S. (2010). The Effect of Self-Efficacy on Academic Success of First-Generation College Sophomore Students. Journal of College Student Development, 50(1), 50-64. doi:10.1353/csd.0.0109

Ward, A. (2020, April 10). Rype Magazine. Retrieved from Rype: https://www.rypeapp.com/blog/major-benefits-of-learningenglish/

Wilson, J., \& Komba, S. C. (2012). The Link between English Language Proficiency and Academic Performance: A Pedagogical Perspective in Tanzanian Secondary Schools. World Journal of English Language, 2(4), 1-10. doi:10.5430/ wjel.v2n4p1

World Economic Forum. (2016). The Future of Jobs Employment, Skills and Workforce Strategy for the Fourth Industrial Revolution. World Economic Forum. Retrieved from http:// www3.weforum.org/docs/WEF_Future_of_Jobs.pdf

Yen, C.-J., \& Liu, S. (2009). Learner Autonomy as a Predictor of Course Success and Final Grades in Community College Online Courses. Journal of Educational Computing Research, 41(3), 347-367. https://doi.org/10.2190/EC.41.3.e

Yeung, P. (2017, September 7). South China Morning Post. Retrieved from https://www.scmp.com/comment/insightopinion/article/2110113/why-cant-chinese-graduates-speakgood-english-blame-teaching

York, T. T., Gibson , C., \& Rankin, S. (2015). Defining and Measuring Academic Success. Practical Assessment, Research \& Evaluation, 20(5), 1-10.

Zajacova, A., Lynch, S. M., \& Espenshade, T. J. (2005, Sep). Selfefficacy, stress, and academic success in college. Research in Higher Education, 46(6), 677-706. 